\title{
Medicinal Plants Used in Traditional Medicine in Aizawl and Mamit Districts of Mizoram
}

\author{
Rama Shankar (Corresponding Author) \\ Ayurveda Regional Research Institute (CCRAS) Itanagar-791111 \\ Tel: 91-221-1498Ｅ-mail: rshankar58@gmail.com
}

M.S. Rawat

National Medicinal Plants Board

Chandralok Building, 36 Janpath, New Delhi 110001

E-mail: msrawat03@rediffmail.com

Received: April 25, 2012 Accepted: May 8, 2012

doi:10.5296/jbls.v4i2.3489 URL: http://dx.doi.org/10.5296/jbls.v4i2.3489

\begin{abstract}
Paper deals with the traditional healing herbs used by Mizo tribe in the treatment of several ailments viz. fever, ringworm, itching, worm infestation, dysentery, diarrhea, high blood pressure, jaundice, ulcer, scabies, kidney stone, piles, fistula, dandruff etc. in the Aizawl and Mamit districts of Mizoram. There is an urgent need of modernization and documentation of such valuable traditional knowledge and verification of their efficacy through clinical trial and to find out their chemical constituents.
\end{abstract}

Keywords: Traditional medicine, Mizoram, Clerodendrum serratum, Solanum kurzii, Centella asiatica.

\section{Introduction}

State of Mizoram is located in the north east corner of India of which the areas of the districts under study lies between $21^{0} 56^{\prime} \mathrm{N}-23^{0} \mathrm{E}$ latitude and $92^{\circ} 16^{\prime}-93^{\circ} 26^{\prime} \mathrm{N}$ longitude, descending in the south east extremity of North eastern region with the formation of sandwich between Myanmar in the east and Bangladesh in the West by sharing an international boundary of 585 kilo meters with these two countries Remaining part of the state is bounded with the state of Tripura in the West and Assam in the north partially the north eastern boundary of the state is 


\section{Mll Macrothink}

also surrounded by Manipur. The state is divided into 8 districts out of which Aizawl and Mamit covered under studies are located in the northeastern part of the state. (Figure 1.)

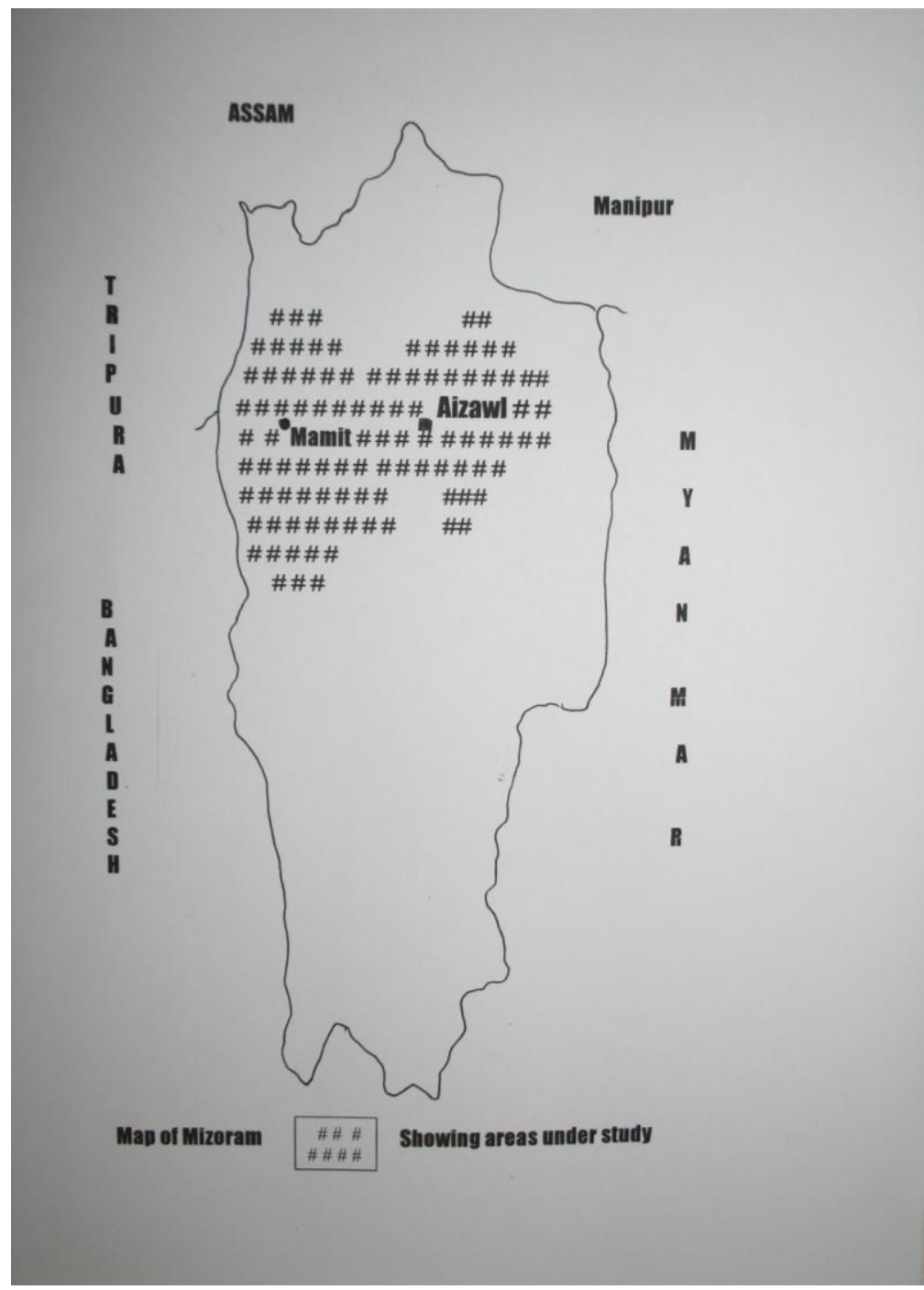

Figure 1.

Information on is available on the use of traditionally used medicines and their distribution in the areas with traditional use of commercially important medicinal plants suitable for developing traditional knowledge for socio- economic upliftment. Information on the medicinal wealth and various aspects of folk lore medicines used by the natives of Mizoram is sufficiently available (Mahati, 1994; Lalramnghinglova, 1996; 1999; Singh et al. 2002; Lalfakzuahla et al., 2007; Rai \& Lalramnghinglova, 2010a, b, c). Medico botanical exploration of districts of Kolasib, Aizawl, and Chaphai had also been made (Rama Shankar, 2009). However, the details of the medicinal plants used by the traditional healers of Aizawl and Mamit districts are insufficiently known Accordingly, the attempt on medico ethno botanical aspects of Aizawl and Mamit districts have been taken under study where in the medicinal plants belonging to established system of medicine i. e. Ayurveda, Unani and Siddha were used by the traditional folk healers in a crude single or combination of drugs for the cure of different diseases as well as methodology of use in comparison to already reported disease and 
methodology. In general, traditional healers use crude drug part either in fresh juice or decoction for healing the ailments. In case of joint pains, headache or other types of pain, poultice or paste of fresh plant is externally used. During the study about 37 such medicinal plants used by traditional healers along with their healing practices and methodology from the districts under study have been recorded and discussed in this paper.

\section{Methodology}

The present study is based on repeated medicinal plants survey in the state of Mizoram covering districts of Aizawl and Mamit. Different demonstration on traditional healing practice was observed under which information on local name and parts used as well as methodology of application and doses were recorded through interaction and discussion along with demonstration of methodology of use. In total 12 villages were covered with an aim to find out some new drug plant or methodology for adding to the recognized system of medicine like Ayurveda, Siddha, Unani and Homoeopathy. To fulfill the goal, the study was carried out with an interaction with the local healers using traditional method of treatment in different 12 villages. Out of 12 villages, only informants under the leadership of Shri R.P. Ropianga from Lengpui have come across to share their knowledge with sufficient knowledge about traditional healing practices and are engaged in treating ailments. Side by side knowledge on common use of medicinal plants used in Ayurveda as single drugs were shared on exchange basis which helped the informers also to increase their herbal knowledge. Methods for systemic utilization and sustainable collection were experienced the local healers for socioeconomic development by undertaking cultivation of these high valued medicinal plants. Voucher specimens were prepared and maintained in the Herbarium of Ayurveda Regional Research Institute Itanagar. Authenticity of the plant herbarium was confirmed by matching the specimens with the authentic samples kept in the Herbarium of Botanical Survey of India, Eastern Circle, Shillong.

\section{Results}

The traditional system of healing includes indigenous medicines used orally or external application of herb, its paste as well as healing processes through sacrifice like ritual or rites for the appeasement of good and relief from evil spirits. Traditional practices for healing ailments is long term process and due to various developmental activities these practices are gradually depleting and very lesser number of herbalists and folk healer are practicing, who are far away from developed cities. State of Mizoram is inhabited by Mizo tribe and they are using various herbal preparations for treating various ailments. Due to developmental activities their numbers and knowledge is being reduced and need their conservation and proper documentation.

This system is still retaining in tribal areas where the traditional practice men are adopting the practice. Information on some of the herbs used in the traditional system of medicines in Mizo community has been emphasized in this paper (Table 1). During the course of study 37 folklore claims were recorded out of which maximum distribution amongst the families goes to Asteraceae with five representatives followed by Verbenaceae with three representatives and families of Apiaceae, Apocynaceae, Euphorbiaceae, Fabaceae, Mimosaceae and Solanaceae 
are represented with two species whereas, in the families like Acanthaceae, Anacardiaceae, Araliaceae, Bignoniaceae, Caricaceae, Caesalpiniaceae, Costaceae, Cucurbitaceae, Dilleniaceae, Lamiaceae, Liliaceae, Malvaceae, Moraceae, Myrtaceae, Poaceae, Rosaceae and Rubiaceae there is only one species used by Mizo tribe of Aizawl and Mamit districts of Mizoram.

Table 1. Medicinal plants used in traditional medicine by healers of Mizoram

\begin{tabular}{|c|c|c|c|}
\hline Botanical name & Family & Local name & Use \\
\hline $\begin{array}{l}\text { Ageratum } \\
\text { conyzoides L. }\end{array}$ & Asteraceae & Lensa & $\begin{array}{l}\text { Fresh leaves crushed and used to stop } \\
\text { bleeding. Juice of leaf used to stop nose } \\
\text { bleeding. }\end{array}$ \\
\hline $\begin{array}{l}\text { Aloe barbadensis } \\
\text { Mill. }\end{array}$ & Liliaceae & Aloe vera & $\begin{array}{l}\text { Leaf pulp ( } 1 \text { tea spoon full) is used thrice a } \\
\text { day in jaundice and other liver disorders. }\end{array}$ \\
\hline $\begin{array}{l}\text { Alstonia scholaris } \\
\text { R.Br. }\end{array}$ & Apocynaceae & $\begin{array}{l}\text { Saptaparna; L. } \\
\text { Montho; }\end{array}$ & $\begin{array}{l}\text { Powder of stem bark }(1 \mathrm{gm}) \text { with luke warm } \\
\text { water twice a day for seven days. If persists } \\
\text { continued till } 10 \text { days to get relief from } \\
\text { malarial fever. }\end{array}$ \\
\hline $\begin{array}{l}\text { Anthocephalus } \\
\text { chinensis (Lam.) } \\
\text { Rich. Ex Wall }\end{array}$ & Rubiaceae & Banphar (Mizo). & $\begin{array}{l}\text { Ripe fruits are edible and acts as appetizer } \\
\text { and protects mouth from mouth ulcer.. }\end{array}$ \\
\hline Artemisia vulgaris L. & Asteraceae & $\begin{array}{l}\text { Nagdamanika; } \\
\text { L. Sai }\end{array}$ & $\begin{array}{l}20-25 \mathrm{gms} \text { of fresh leaf boiled in } 200 \mathrm{ml} \text {. } \\
\text { water till reduced } 50 \mathrm{ml} \text {. taken twice a } \\
\text { day before meal in malarial fever till } \\
\text { complete relief. }\end{array}$ \\
\hline $\begin{array}{l}\text { Aralia montana } \\
\text { Blume }\end{array}$ & Aralliaceae & Kotabell. & $\begin{array}{l}\text { Leaf decoction ( } 10 \text { gms of fresh leaf in } \\
\text { water) used thrice a day during malarial } \\
\text { fever till one week/ till relief. }\end{array}$ \\
\hline $\begin{array}{l}\text { Artocarpus } \\
\text { heterophyllus Lam. }\end{array}$ & Moraceae & Kathal & $\begin{array}{l}\text { Paste of leaves is locally used on skin } \\
\text { diseases like ring worm and itching till } \\
\text { complete relief. }\end{array}$ \\
\hline $\begin{array}{l}\text { Bauhenia variegata } \\
\text { L. }\end{array}$ & Caesalpiniaceae & Vaufavang. & $\begin{array}{l}\text { One tea spoon of powdered dried buds } \\
\text { taken with fresh water thrice a day as a } \\
\text { remedy for piles and dysentery. Same } \\
\text { process is adapted for worm infestation. }\end{array}$ \\
\hline $\begin{array}{l}\text { Benincasa hispida } \\
\text { (Thunb.) Cogne }\end{array}$ & Cucurbitaceae & Manipat & $\begin{array}{l}\text { Three pieces each with } 70 \text { gms of fruit is } \\
\text { taken a day in diarrhea. Three pieces are } \\
\text { anthropological concept for remedy. }\end{array}$ \\
\hline $\begin{array}{l}\text { Callicarpa arborea } \\
\text { Roxb. }\end{array}$ & Verbenaceae & $\begin{array}{l}\text { Priyangu } \\
\text { Hnahkiah }\end{array}$ & $\begin{array}{l}\text { Decoction of 2-3 leaves pound in water or } \\
\text { made decoction and taken twice a day } \\
\text { before meal in gastric ulcer. }\end{array}$ \\
\hline $\begin{array}{l}\text { Cathranthus roseus } \\
\text { (L.) G.Don }\end{array}$ & Apocynaceae & Sadavahar & $\begin{array}{l}\text { 3-4 flowers and leaf taken orally as a } \\
\text { remedy of diabetes. }\end{array}$ \\
\hline Carica papaya L. & Caricaceae & Tingfanghana & $\begin{array}{l}\text { About } 100 \text { gms fresh unripe fruits taken } \\
\text { orally in dysentery and vomiting. } \\
\text { Seeds chewed directly for expelling } \\
\text { intestinal worm. } \\
\text { Paste of leaf used in ring worm } \\
\text { Unripe fruit cooked with chicken is given } \\
\text { in malaria }\end{array}$ \\
\hline $\begin{array}{l}\text { Centella asiatica } \\
\text { (L.) Urb. }\end{array}$ & Apiaceae & Lambak & $\begin{array}{l}5 \text { to } 8 \text { fresh leaves are eaten thrice a day } \\
\text { during the period of stomach ache, kidney } \\
\text { stone. }\end{array}$ \\
\hline
\end{tabular}




\begin{tabular}{|c|c|c|c|}
\hline & & & $\begin{array}{l}\text { It improves loss of appetite and act as } \\
\text { remedy for jaundice } \\
\text { It is also considered that taking up 5-10 } \\
\text { fresh leaves in the morning also improves } \\
\text { eye vision. }\end{array}$ \\
\hline $\begin{array}{l}\text { Chromolena odorata } \\
\text { (L.) King. \&Rob. }\end{array}$ & Asteraceae & Thangsam & Leaf paste stops bleeding. \\
\hline $\begin{array}{l}\text { Clerodendrum } \\
\text { viscosum Vent. }\end{array}$ & Verbenaceae & Phuihnam. & $\begin{array}{l}\text { Decoction of two to three leaves is used as } \\
\text { shampoo to remove dandruff. } \\
\text { Root Paste used in scabies through external } \\
\text { application. }\end{array}$ \\
\hline $\begin{array}{l}\text { C. } \text { serratum (L.) } \\
\text { Moon }\end{array}$ & Verbenaceae & Phuihnamshak & $\begin{array}{l}\text { Leaf decoction of } 4-5 \text { leaves used in } \\
\text { jaundice twice a day and improves high } \\
\text { blood pressure. }\end{array}$ \\
\hline $\begin{array}{l}\text { Costus speciosus } \\
\text { (Koen.) Sm. }\end{array}$ & Costaceae & $\begin{array}{l}\text { Kebuk, Kushtha; } \\
\text { Sambul }\end{array}$ & $\begin{array}{l}\text { Rhizome paste taken in removal of kidney } \\
\text { stone. }\end{array}$ \\
\hline Crotolaria juncea $\mathrm{L}$. & Fabaceae & $\begin{array}{l}\text { Sana; } \\
\text { Tumthang }\end{array}$ & $\begin{array}{l}\text { Flower used as vegetable with the concept } \\
\text { of high nutrious and worm repellent. }\end{array}$ \\
\hline Dillenia indica $\mathrm{L}$. & Dilleniaceae & Kawsthindang & $\begin{array}{l}10 \mathrm{ml} \text {. of juice of leaves, bark and fruits } \\
(1: 1: 3) \text { for twice a day, used in diarrhea till } \\
\text { complete relief. }\end{array}$ \\
\hline $\begin{array}{l}\text { Emblica officinales } \\
\text { Gaertn. }\end{array}$ & Euphorbiaceae & Sinhlu. & $\begin{array}{l}\text { Bark pounded in water two tea spoon full } \\
\text { taken twice daily as remedy for dysentery. } \\
\text { Bark used in fish poisoning. }\end{array}$ \\
\hline $\begin{array}{l}\text { Eryngium foetidum } \\
\text { Lam. L. }\end{array}$ & Apiaceae & Bahkhawr & $\begin{array}{l}\text { Decoction of fruits }\left(\begin{array}{ll}10 \mathrm{ml} .\end{array}\right) \text { used in } \\
\text { dysentery. } \\
\text { Leaf juice externally applied on forehead or } \\
\text { shriveling fever. } \\
\text { Leaf is taken as incense for flavour of } \\
\text { vegetable. }\end{array}$ \\
\hline $\begin{array}{l}\text { Indigofera prostrata } \\
\text { Willd. }\end{array}$ & Fabaceae & Sekhupthur & $\begin{array}{l}\text { Boiled seeds are taken orally in piles and } \\
\text { fistula. }\end{array}$ \\
\hline $\begin{array}{l}\text { Leucas indica (L.) R. } \\
\text { Br. ex Vatke }\end{array}$ & Lamiaceae & & Leaf juice used for control of nose bleeding \\
\hline Mangifera indica $\mathrm{L}$. & Anacardiaceae & Theihai & $\begin{array}{l}\text { Juice of } 1-2 \text { tender leaves used in diarrhea, } \\
\text { twice daily. }\end{array}$ \\
\hline $\begin{array}{l}\text { Mikania scandens } \\
\text { (L.) Willd. }\end{array}$ & Asteraceae & Japan Lao & $\begin{array}{l}\text { Plant juice is used thrice a day in dysentery } \\
\text { and other stomach troubles. }\end{array}$ \\
\hline Mimosa pudica $\mathrm{L}$. & Mimosaceae & Lajjalu & $\begin{array}{l}\text { Leaf juice or decoction is used in jaundice. } \\
5-6 \text { mature seeds are given to alcohol } \\
\text { addicts which makes them free from } \\
\text { addiction. }\end{array}$ \\
\hline $\begin{array}{l}\text { Oroxylum indicum } \\
\text { (L.) Benth. }\end{array}$ & Bignoniaceae & Archangkon & $\begin{array}{l}\text { Leaf decoction is used by gargling in } \\
\text { tonsillitis } \\
\text { Stem bark is used in Malaria, Jaundice and } \\
\text { Typhoid }\end{array}$ \\
\hline $\begin{array}{l}\text { Parkia roxberghii } \\
\text { D.Don. }\end{array}$ & Mimosaceae & Zawngtah & $\begin{array}{l}\text { Root juice (1-2 tea spoon full) used in fever. } \\
\text { Young green pods eaten raw, seeds boiled } \\
\text { and taken as vegetable. }\end{array}$ \\
\hline $\begin{array}{l}\text { Phyllanthus amarus } \\
\text { Schum \& Thom. }\end{array}$ & Euphorbiaceae & Mithisunhlu & $\begin{array}{l}\text { Plant juice with 5-6 leaves of Centella } \\
\text { asiatica is used in jaundice }\end{array}$ \\
\hline Phyllostachys & Poaceae & Montho & Fruit juice is applied on affected parts of \\
\hline
\end{tabular}




\begin{tabular}{|c|c|c|c|}
\hline $\begin{array}{l}\text { bamboosoides Sieb. } \\
\text { and Zucc. }\end{array}$ & & & skin diseases like eczema and ring worm. \\
\hline $\begin{array}{l}\text { Portulacca oleracea } \\
\text { L. }\end{array}$ & Portulaccaceae & Hmutau & $\begin{array}{l}\text { Two tea spoon full of root decoction taken } \\
\text { as a remedy for dysentery and diarrhoea }\end{array}$ \\
\hline Psidium guajava $\mathrm{L}$. & Myrtaceae & Guava & $\begin{array}{l}\text { Fresh leaves are used in dysentery and } \\
\text { cholera }\end{array}$ \\
\hline $\begin{array}{l}\text { Solanum kurzii } \\
\text { Brace ex Prain }\end{array}$ & Solanaceae & Tawkte & $\begin{array}{l}\text { Fresh berries ( } 1 \text { gm. Powdered) are used } \\
\text { three times a day in reducing blood sugar }\end{array}$ \\
\hline Solanum torvum $\mathrm{Sw}$. & Solanaceae & Tawkte & $\begin{array}{l}\text { Fresh berries ( } 1 \text { gm. Powdered) are used } \\
\text { three times a day in reducing blood sugar }\end{array}$ \\
\hline $\begin{array}{l}\text { Spilanthus } \\
\text { paniculata Wall. Ex. } \\
\text { DC. }\end{array}$ & Asteraceae & Arisato & Flower crushed and given in stomach ache. \\
\hline $\begin{array}{l}\text { Thunbergia } \\
\text { gramndiflora Roxb. }\end{array}$ & Acanthaceae & Vako & $\begin{array}{l}\text { Root powder or paste }(1 \mathrm{gm}) \text { is taken twice } \\
\text { a day in removal of kidney stone and } \\
\text { jaundice. }\end{array}$ \\
\hline Urena lobata L. & Malvaceae & & $\begin{array}{l}\text { Root pounded in water is given in Kidney } \\
\text { disorders }\end{array}$ \\
\hline
\end{tabular}

\section{Discussion and Conclusion}

During exploration of traditional healing practices in the districts of Kolasib, Aizawl, and Mamit in Mizoram it was observed that several medicinal plants described in established Ayurvedic system of medicines are used by traditional healers of Mizo community. Though several workers have reported the folklore medicinal plants of Mizoram (Mahati, 1994; Lalramnghinglova, 1996; 1999; Singh et al. 2002; Lalfakzuahla et al., 2007; Rama Shankar et al., 2009; Rai \& Lalramnghinglova, 2010a, b, c.) however, reports on methodology and dose of the drugs used for those folklores which are used in different system of medicines was still lacking and the present communication deals with the details of the drugs which are being used in different doses either as single drug or compound formulations.

The folk medicinal plant used by traditional healers are confined to most of the diseases prevalent in different areas like diarrhea, dysentery cold cough and skin diseases which are very prevalent in the state due to high moisture content and problems arising through drinking water. During exploration it was also found that some of the traditional healers have developed their own herbal garden for use of these fresh drugs for treatment. Several endangered species like Oroxylum indicum Cissamplelos pareira, Stephania japonica are also being used by traditional healers. This knowledge of traditional healers needs to be made popularized by taking them under various formulations.

Study reveals that distribution of these medicinal plants are being rare and endangered in their natural habitat due to several factors which need to be conserved and cultivated for their perpetual existence. Simultaneously, traditional knowledge should be documented, and preserved for further studies. Some species viz. Aralia montana (Kotabell), Indigofera prostrata (Sekhupthur), Parkia roxberghii (Zawngtah) are not known to established system of medicines, whereas Mizo community are using these plants in treatment of specific ailments. There is a good scope for verifying the efficacy of these plants, detection of chemical constituents present in different parts of such plants and further clinical trial. During study it was observed that maximum number of traditionally used plants were belonging to family 


\section{Al Macrothink}

Journal of Biology and Life Science ISSN 2157-6076 2013, Vol. 4, No. 2

Asteraceae with five representatives which in turn was followed by Verbenaceae with three representatives, Apiaceae, Apocynaceae, Euphorbiaceae, Fabaceae, Mimosaceae and Solanaceae, having two representatives whereas the families having only single representative were Acanthaceae, Anacardiaceae, Araliaceae, Bignoniaceae, Caricaceae, Caesalpiniaceae, Costaceae, Cucurbitaceae, Dilleniaceae, Lamiaceae, Liliaceae, Malvaceae, Moraceae, Myrtaceae, Poaceae, Rosaceae and Rubiaceae.

\section{Acknowledgement}

The authors are thankful to Dr. Ramesh Babu Devalla, Director General, Central Council for Research in Ayurveda and Siddha New-Delhi for encouragement and financial assistance. Authorities of Botanical Survey of India, Eastern Circle, Shillong are also thankfully acknowledged for help in consulting Herbarium. Thanks are also due to traditional healers Shri Lalrinsangi, Lalmumkimi, K. Rothangpui, Lalhuila and K. Lalhumpui and Shri R.P. Ropianga for sharing their information.

\section{References}

Lalfakzuahla, R. H., Lalramnghinglova, H., \& Kayeng, H. (2007). Ethnobotanical usage of plants in Western Mizoram, Ind J Trad Knowledge, 6(3), 486-493.

Lalramnghinglova, H. (1996). Ethnobotany of Mizoram, a preliminary survey, $J$ Econ

Taxonomic Botany (Addnl series), 12, 439-459.

Lalramnghinglova, H. (1999). Ethnobiology in Mizoram State: Folklore Medico zoology. Bull Indian History of Medicine, 29(2), 123-1248.

Mahati, Niti, (1994). Tribal Ethno Botany of Mizoram, Inter India publication, New Delhi.

Rai, P. K., \& Lalramnghinglova, H. (2010a). Lesser known ethnomedicinal plants of MizoramNorth East India: An Indoburman hotspot region. J Medicinal Plants Research, 4(13), 1301-1307.

Rai, P. K., \& Lalramnghinglova, H. (2010b). Ethnomedicinal plant resources of Mizoram India implication of traditional knowledge in health care, Ethnobotanical Leaflets, 14, 224-305.

Rai, P. K., \& Lalramnghinglova, H. (2010c). Threatened and less known ethnomedicinal plants of an Indo burma hotspot region, conservation implications, Environ.

Rama Shankar, Rawat M. S., Majumder, \& R., Boruah D. (2009). Medico ethno botany of Mizoram (Kolasib, Aizawl, Champhai and Darlawn districts. J Drug Res in Ayur \& Siddha, $30(3-4), 27-40$.

Singh, N. P., Singh, K. P., \& Singh, D. K. (2002). Flora of Mizoram Vol. I, (Botanical Survey of India, Kolkata). 


\section{Copyright Disclaimer}

Copyright reserved by the author(s).

This article is an open-access article distributed under the terms and conditions of the Creative Commons Attribution license (http://creativecommons.org/licenses/by/3.0/). 